\title{
Фоторепортаж в современной прессе
}

Николай Ворон

В статье рассматриваются особенности фоторепортажа в искусстве и фотожурналистике, практика использования его на страницах периодической печати. Обозначены новые моменты в иллюстрировании современной прессы, выявлены семантические аспекты фотопубликаций, их соотнесенность с жанром фоторепортажа.

Ключевые слова: фотожурналистика, фоторепортаж, способ съемки, жанр, фотоиллюстрация.

DOI: 10.30547/mediaalmanah.6.2020.4448
@ Ворон Николай Иванович кандидат филологических наук, старший преподаватель кафедры фотожурналистики и технологий СМИ факультета журналистики МГУ имени М.В. Ломоносова (г. Москва, Россия), nikpinskij@mail.ru
Среди форм отображения современных реалий особое место занимает фоторепортаж. Об этом можно судить, в частности, и по опубликованным в разные годы научным изданиям, исследующим практику фоторепортажа. Фотографию как вид искусства изучали Л.П. Дыко, Е.А. Иофис (1960), Л.Ф. Волков-Ланнит (1967), А.С. Вартанов (1983), С.А. Морозов (1985), А.И. Лапин (2015), В.И. Михалкович, В.Т. Стигнеев (1989); как средство отображения действительности в журналистике - Г.В. Копосов, Л.Н. Шерстенников (1967), И.Д. Бальтерманц (1981), Н.И. Ворон (2012), Г.М. Чудаков $(1982,1983)$, Е.И. Пронин, Е.Е. Пронина (1988), В.М. Песков (2003), Е.Л. Мжельская (2005), А.И. Беленький (2016), В.М. Березин (2016).

В художественной фотографии главным, безусловно, является эстетический аспект. Фотожурналистика же решает прагматические задачи, предоставляя читателю визуальную информацию, художественный аспект в данном случае может обнаруживаться как сопутствующий. Подтверждает это ставший хрестоматийным пример из журналистской практики В. Тарасевича, снявшего фотоочерк "Московский государственный университет», кадр из которого под названием «Поединок» наделен образным звучанием. Более того, он обрел самостоятельную жизнь и используется, 
в частности, как образ ученого на телевидении в передаче «Академия».

Другой признак: фотохудожник, в отличие от фотожурналиста, воплощает свой замысел, как правило, не в многокадровой публикации, а в одиночном снимке, и его можно сравнить с живописцем, создающим полотно. Однако обрести равный живописцу статус может и фотожурналист, что наглядно демонстрирует автор «Поединка». И хотя это частный случай, примеров, когда фотожурналист проявляет способность работать в разных амплуа, можно привести множество. Так, в книге С.А. Морозова «Творческая фотография» (1985) представлены фотоработы как «чистых» фотохудожников, так и газетных и журнальных фотокорреспондентов, отдельные снимки которых обрели статус художественных.

\section{Многозначность термина}

Термином «фоторепортаж» обозначается и один из жанров фотожурналистики, и способ съемки, и метод съемки (правда, в данном случае речь идет о техническом моменте - съемке без вмешательства в ход события). Именно репортажный способ съемки и сближает фотожурналиста и фотохудожника (последнему к тому же не противопоказана постановочная съемка), однако, запечатлевая жизнь "врасплох», каждый из них решает разные творческие задачи.

Фотохудожник назовет съемку жизненных ситуаций «жанром». Запечатлевая действительность в форме художественного образа, он реализует «художественную рефлексию своего внутреннего мира» (В.Н. Агеев, 2002: 110), а зритель - чувственное восприятие отображенного в снимке. Подчеркнем, ценность художественного творчества, в том числе художественной фотографии, связана с удовлетворением эстетических потребностей человека, вне этого оно теряет смысл - художник мыслит категориями эстетики, а это значит, что и в фотоискусстве эстетические ценности рассматриваются как главный и постоянный признак.

Фотожурналист запечатленное событие назовет «фоторепортажем». И дело не в названии как таковом, а в том, что, как заметил исследователь гуманитарных наук М.М. Бахтин (1979: 241), «в каждой сфере бытуют и применяются свои жанры, отвечающие специфическим условиям данной сферы». Бытие журналистики, и фотожурналистики в частности, определяется ее социально-политической действенностью. А это значит, что фотожурналист вырабатывает и применяет на практике те формы отображения социальных реалий, которые позволяют ему достичь этой действенности. И в этих формах в большей мере обнаруживается приверженность эмпиризму фактов и событий, а не мысли в чувственном воплощении. Иными словами, характер отображения фактов и событий в фотожурналистике может варьироваться от протокольно-документального до эстетически значимого.

\section{Индикатор фотожурналистики}

Уяснив сущность репортажного способа съемки как фактора, сближающего разные сферы творчества, сосредоточим внимание на его проявлениях в фотожурналистике, на том, что «поставляет» фотокорреспондент на страницы периодических изданий.

Ранее было отмечено, что фотожурналист привержен многокадровым публикациям. Такое утверждение бесспорно, когда речь идет о жанре фоторепортажа, назначение которого отображать события современной жизни: фоторепортер «прослеживает» и одновременно «запечатлевает» их в ряде снимков. Но фоторепортаж не единственная форма отображения в фотожурналистике. Как магистральный в фотожурналистике следует определить репортажный способ съемки, поскольку из него «произрастают» и другие жанры в этой сфере творческой деятельности, за исключением фотомонтажа, который можно 
уподобить жанру фельетона или памфлета в журналистике.

Но фотозаметка (фотофакт), фотокорреспонденция, фотоочерк и другие практикуемые в фотожурналистике жанры - плоды репортажного способа съемки, различающиеся типологическими признаками и методиками воплощения. Такое родство по способу съемки порой приводит к тому, что данные жанры обозначают на страницах прессы единым термином - «фоторепортаж». Безусловно, для читателя это не имеет принципиального значения, однако таким образом границы жанра, несомненно, размываются. Отметим также, что сам репортажный способ съемки, используемый фоторепортерами фактически во всех формах отображения действительности, нередко отождествляют с понятием «фотожурналистика». И здесь, по нашему мнению, нет теоретической погрешности. Съемка без режиссуры действительности должна восприниматься как закономерность в работе фотокорреспондента, поскольку читатель ждет на страницах прессы результаты именно такой съемки.

Обратимся к публикациям журнала «Огонек». Четырнадцать снимков С. Голикова, объединенных в материале «К пику возможностей» (2019, № 47), отобразили восхождение людей с ограниченными возможностями на Килиманджаро - самую высокую горную вершину в Африке. В публикации Н. Радуловой и Д. Лебедева «И тепло, и в розах» (2020, № 4), посвященной 225-летию павловопосадского платка, изобразительный ряд фактически повторил технологическую цепочку производства. «Век просвещения» М. Абрамовой и К. Кормилициной (2020, №5) соединил воспоминания о прошлом и один день из настоящего знаменитой пензенской гимназии. Фоторепортаж Е. Никоновой и Н. Нехлебовой «Шестьсот лет местные» (2020, № 8) в одиннадцати снимках рассказал о буднях села Варзуга - старейшем поселении на Кольском полуострове. Г. Розов и
В. Ошеев в публикации «В Москве летать охота» $(2020$, № 3) предоставили читателю виды столицы с высоты птичьего полета.

Все названные материалы роднит способ съемки - репортажный. Но если восхождение на Килиманджаро представлено в жанре классического фоторепортажа, то другие публикации имеют разные семантические оттенки. В «Веке просвещения» прослеживается зарисовочный акцент, в материале «Шестьсот лет местные» подмечены не только бытовые моменты, но и хозяйственные проблемы, что сближает публикацию с фотокорреспонденци ей. Фотосерия «В Москве летать охота» совершенно лишена событийного акцента и наиболее отдалена от жанра фоторепортажа, а снимки в публикации «И тепло, и в розах" представляют собой красочные иллюстрации к тексту - основному информационному компоненту.

В журнале «Огонек» все проанализированные фотопубликации обозначены термином «фоторепортаж», назначение которого запечатлевать события - проще говоря, происходящее в мире на глазах фотожурналиста. Однако в большинстве съемок представлена действительность свершившаяся. Подобное явление обнаруживается и в других периодических изданиях, и его можно обозначить как тенденцию к фактографии в современном фоторепортаже.

Уже отмечалось, что репортажный способ съемки - корневая основа и других жанров фотожурналистики, поэтому их нельзя исключать из поля зрения при прослеживании особенностей в иллюстрировании современной прессы. Прежде всего, это одиночные фотографии, чаще всего представляющие собой фотозаметки или просто «довесок» к текстовым публикациям. Это направление в использовании изобразительного материала изобилует натуралистическими документальными снимками действительности. Натуралистический снимок, как правило, лишен авторской 
интерпретации, а пространственно-временную конкретность изображения можно сравнить с понятийным языком. Такая особенность запечатлевать реалии мира присуща информационным жанрам, наиболее часто практикуемым в фотожурналистике и широко представленным в газетах. Например, «Московский комсомолец" из номера в номер в рубрике Non-stop, расположенной на второй полосе, всегда размещает фотозаметку, остальные полосы, как правило, заполняют фотоиллюстрации к текстовым материалам. «Литературная газета» в постоянной рубрике «Фотоглас» также публикует фотозаметку (естественно, из культурной жизни) и дополняет материалы номера фотоиллюстрациями.

На страницах периодических изданий можно обнаружить и «внешний» вариант репортажности: вместо одиночного портретного снимка материал сопровождает ряд фотоизображений автора текста, излагающего свою мысль в ходе интервью. Так, еженедельник «Аргументы и факты» (2016, № 46) сопроводил выступление Владимира Хотиненко («Посмотреть в глаза») тремя фотографиями В. Христофорова, запечатлевшими режиссера в полемическом азарте. И это не единственный случай - такую форму подачи изобразительного материала, в частности, практикует газета «Коммерсантъ».

Довольно распространенным явлением в иллюстрировании становится размещение в текстовых публикациях символических снимков. Но одна из особенностей символа заключается в том, что он обозначает, но не сообщает, не информирует. Здесь уместно привести замечание философа и филолога А.Ф. Лосева (1995: 130) о том, что «в символе действительность не дана, а задана». Естественно, символ не сообщает новостей. Такие фотографии нередко можно видеть на страницах газеты «Известия». Например, заглавный текстовой материал «Дешевле некуда» (2018, № 158) о том, что Центробанк не видит перспектив снижения ставок по кредитам, сопроводили два фотоизображения: эмблема банка и нерезкий силуэт делового человека на его фоне (намек на действительность налицо). Газета «Коммерсантъ» (2020, № 39) в текстовую публикацию «Три большие разницы» о поправках в Основной закон о русском народе, Боге и браке вмонтировала фотоизображение фрагмента кремлевской стены с куполом и крестом на дальнем плане (дополняющее выразительное фотографическое решение без новостного начала).

Символический акцент в подаче изобразительного материала на страницах современных периодических изданий можно обнаружить и в многокадровых публикациях. Газета «Известия» (2019, № 159) проиллюстрировала рассуждения А. Туманова и Н. Васильевой «Крымский стиль» о форуме «Таврида-АРТ» фотографиями, смонтированными в виде лепестков объектива фотоаппарата. По мнению редакции, символ запечатлевающего объектива - оригинальная подача отображенных моментов действительности, которая должна была привлечь внимание читателя. Похожий символ «Известия» использовали не единожды - например, в материале Е. Лория и Е. Ладиловой «Мир чемпионата» (2018, № 105), посвященном футбольному первенству планеты. В данных примерах выразительность разминулась с изобразительностью: необычность подачи фотографий, конечно, читатель замечает, но этим ее роль и ограничивается.

Но в современной прессе нередко встречаются символические фотопубликации, в которых информативность снимка обусловливается именно его выразительными качествами. Журнал «Огонек» $(2017$, № 29) открывает материал о Хакасии «Бескрайний музей» вопросом, почему «земля древних богов» становится культурным центром притяжения, и выразительно отмечает это притяжение заглавным снимком А. Жданова. Фотоизображение напоминает земную сферу и обретает образное звучание. 
Снимок стал символом «бескрайнего музея». Этот пример сродни упоминавшемуся ранее «Поединку» В. Тарасевича. В обоих случаях художественная образность предопределяется авторской трактовкой объектов, для которой найдены соответствующие выразительные средства.

Приведенные примеры символических фотоизображений в «Известиях» и «Огоньке» не противоречат друг другу. Символичность может обнаруживаться как в натуралистичной фотокопии действительности, так и в ее художественном воплощении. Но в документальном снимке она проявляет себя как непостоянное качество и часто решает ограниченную задачу - привлечь внимание. Художественной образности символ предписан (он содержательный элемент), но в прессе он редкость. Однако, если символ в натуралистической копии «потеснит» новостные фотопубликации, проявит себя как уверенная тенденция, можно будет констатировать: информативность в прессе идет на убыль.

За различными подходами к иллюстрированию материалов периодической печати просматривается желание изданий обрести свой стиль. Но во всех случаях поиски идут на основе репортажа - способа съемки или жанра. И здесь важно сохранить вектор фоторепортажа: публикация должна предоставлять качественную визуальную информацию, говорить на своем языке и воздействовать на читателя.

\section{Библиография}

Агеев В.Н. Семиотика. М.: Изд-во «Весь Мир», 2002.

Бальтерманц И.Д. Специфика содержания и формы фотожурналистики. М.: Изд-во Моск. ун-та, 1981.

Бахтин М.М. Эстетика словесного творчества. М.: Искусство, 1979.

Беленький А.И. Фотожурналистика в современных СМИ. СПб.: Изд-во СПбГУ, 2016.

Березин В.М. Фотожурналистика. М.: Юрайт, 2016.

Вартанов А.С. Фотография: документ и образ. М.: Планета, 1983.

Волков-Ланнит Л.Ф. Искусство фотопортрета. М.: Искусство, 1967.

Ворон Н.И. Жанры фотожурналистики. М.: Фак. журн. МГУ, 2012.

Дыко Л.П., Иофис Е.А. Фотография, ее техника и искусство. М.: Искусство, 1960.

Копосов Г.В., Шерстенников Л.Н. В фокусе - фоторепортер. М.: Молодая гвардия, 1967.

Лапин А.И. Фотография как... М.: Тримедиа, 2015.

Лосев А.Ф. Проблема символа и реалистическое искусство. М.: Искусство, 1995.

Мжельская Е.Л. Редакторская подготовка фотоизданий. М.: Аспект Пресс, 2005.

Михалкович В.И., Стигнеев В.Т. Поэтика фотографии. М.: Искусство, 1989.

Морозов С.А. Творческая фотография. М.: Планета, 1985.

Песков В.М. Любовь фотография. М.: ТЕРРА - Кн. клуб, 2003.

Пронин Е.И., Пронина Е.Е. Социокультурная функция фоторепортажа // Фотография и журналистика. Рига: НМЦ им. Э. Мелнгайлиса, 1988.

Чудаков Г.М. Фотография в прессе: содержание, форма, жанровая структура // Советское фото. 1982. № 8, 10, 12; 1983. № 1. 